Reviu Akuntansi dan Bisnis Indonesia, Vol. 4 No. 1, Hlm: 43-55, Juli 2020

Website: http://journal.umy.ac.id/index.php/rab

\title{
Dampak Keberadaan Badan Usaha Milik Desa (BUMDes) Terhadap Peningkatan Kesejahteraan Masyarakat (Studi pada Badan Usaha Milik Desa (BUMDes) di Desa Ponggok, Tlogo, Ceper dan Manjungan Kabupaten Klaten)
}

\author{
Aulia Tafhana Arindhawati * \& Evy Rahman Utami ${ }^{1}$ \\ 'Program Studi Akuntansi Univeritas Muhammadiyah Yogyakarta.
}

I N F O A R T I K E L

\section{Kata Kunci:}

Badan Usaha Milik Desa (BUMDes), Kesejahteraan

Masyarakat

Jenis Artikel:

Penelitian Empiris

Korespondensi:

tafhanaaulia98@gmail.com
A B S T R A K

\section{Latar Belakang:}

Transparancy sangat penting untuk meningkatkan publikasi kepada masyarakat agar masyarakat mengetahui dengan jelas kondisi aset yang dimiliki. Fokus penelitian ini menggambarkan bagaimana keberlanjutan pengelolaan BUMDes dimasa yang akan datang, tanggungjawab dari pengelolaan BUMDes dan transparansi pengelolaan BUMDes yang diberikan kepada masyarakat di Pemerintah Kabupaten Klaten.

Tujuan:

Penelitian ini bertujuan untuk mengkaji Keberadaan Badan Usaha Milik Desa (BUMDes) terhadap Peningkatan Kesejahteraan Masyarakat. Penelitian ini bertujuan untuk mengetahui apakah dengan keberadaan BUMDes bisa meningkatkan kesejahteraan masyarakat.

\section{Metode Penelitian:}

Teknik pengumpulan data yang digunakan dalam penelitian ini adalah dengan wawancara untuk menggali informasi yang diperlukan. Penelitian ini pemilihan informan dipilih secara purposive sampling. Informan yang dipilih dalam penelitian ini adalah Ketua BUMDes, Staff BUMDeS, Kepala Desa, Tokoh Masyarakat sekitar.

\section{Hasil Penelitian:}

Hasil penelitian ini menunjukkan bahwa keberadaan BUMDes bisa meningkatkan kesejahteraan masyarakat meskipun ada salah satu BUMDes yang belum bisa menyumbang ke PADes dan belum ada remunerasi tetapi masyarakatnya mendukung keberadaan BUMDes dengan jiwa sosialnya yang tinggi untuk ikut andil dalam memajukan BUMDes tersebut dan masyarakat merasa perbedaan sebelum ada BUMDes dan setelah ada BUMDes.

\section{Keterbatasan Penelitian:}

Batasan ini bertujuan agar pembahasan yang dilakukan dalam penelitian hanyalah masalah yang akan diteliti oleh peneliti. Ruang lingkup dalam penelitian ini terbatas pada lokasi penelitian dan informan yang dipilih.

Keaslian/Novetly Penelitian:

Penelitian BUMDes merupakan topik baru, khususnya penelitian untuk di Pemerintah klaten. Sehingga, keaslian dari penelitian ini menjadi diskusi baru khusunya wilayah klaten. 


\section{PENDAHULUAN}

Undang-Undang No 6 Tahun 2014 berisi bahwa desa harus dilindungi dan diberdayakan agar menjadi kuat, maju, mandiri dan demokratis sehingga dapat menciptakan landasan yang kuat dalam melaksanakan pemerintah dan pembangunan menuju masyarakat adil, makmur dan sejahtera. Desa adalah unit kecil dari suatu negara yang paling dekat dengan masyarakat dan bersentuhan langsung terhadap kebutuhan masyarakat untuk kesejahteraan. Sejalan dengan Peraturan Menteri Dalam Negeri Nomor 113 Tahun 2014 Pasal 1 yang mengatakan bahwa desa merupakan kesatuan masyarakat yang mempunyai batas wilayah dan berwenang untuk mengurus dan mengatur masyarakat sesuai dengan prakarsa masyarakat, hak tradisional yang sudah diakui oleh Negara Kesatuan Republik Indonesia (NKRI).

Undang-Undang No 32 Tahun 2004 Tentang Pemerintah Daerah, Desa dapat mendirikan Badan Usaha Milik Desa sesuai dengan potensi desa guna untuk mewadahi aktivitas dan perekonomian masyarakat desa. Dengan pendirian BUMDes maka bisa menggali kreatifitas masyarakat desa dan sumber daya desa yang akan menghasilkan pendapatan asli daerah dari berbagai usaha yang telah dikelola BUMDes serta pembangunan desa dan perekonomian desa menjadi lebih meningkat. Teori social enterprise yaitu organisasi atau usaha yang menggabungkan tujuan sosial dengan mengejar keberhasilan keuangan di pasar swasta (Young et al., 2014). Kerangka definisi social enterprise harus mengakui bahwa social enterprise mengembangkan dalam bidang politik, sosial, dan konteks ekonomi yang membantu menentukan tujuan dan cara operasi. Di Eropa social enterprise dibentuk sebagai tujuan sosial dalam memahami penekanan pemerintah yang demokratis dan berbentuk koperasi (Young et al., 2014). Pada penelitian Ridley-duff \& Rorry (2015) selama krisis ekonomi di Inggris dan Amerika Serikat pada tahun 2007-2008 terdapat banyak bantuan dalam bentuk ekonomi sosial yang diberikan kepada organisasi-organisasi di Inggris dan Amerika Serikat. The New Economics Foundation (NEF) memperkirakan empat bank di Inggris menerima subsidi dengan nilai \$ 35 miliar pada tahun 2012 dan mengambil tambahan subsidi perbankan kumulatif hingga $\$ 193$ milyar sejak 2007, enam kali lebih besar dari nilai hibah dan sumbangan untuk sektor amal, dan hampir dua kali lipat dari omset sektor koperasi, oleh karena itu social enterprise dijadikan sebagai upaya untuk memprivatisasi pengiriman layanan publik (Ridley-duff \& Rorry, 2015)

Di seluruh Indonesia tercatat hingga pada bulan November 2018 sudah mencapai 41 ribu unit Badan Usaha Milik Desa (BUMDes) yang tersebar di 74.957 desa yang ada di Indonesia. Ada 64\% desa yang sudah memiliki BUMDes. Sebagian besar BUMDes yang terbentuk menjalankan usaha wisata yang memperlihatkan panorama lingkungan, kuliner sebagai ciri khas makanan dari masingmasing desa (KEMENDES PDTT, n.d.). Sebanyak 41 ribu unit BUMDes yang sudah berdiri di Indonesia akan tetapi belum sepenuhnya memiliki perkembangan yang baik, dan masih memerlukan pedampingan supaya mampu menampung aktivitas ekonomi yang tumbuh di desa dan bisa meningkatkan kesejahteraan masyarakat desa. Pendirian BUMDes bukan hanya dilegalkan dengan Perdes tetapi juga diharapkan bisa berkembang secara maksimal (KEMENDES PDTT, n.d.).

Pembentukan BUMDes tidak hanya meniru dari desa-desa lain akan tetapi harus sesuai dengan potensi masyarakat setempat, potensi desa atau kekayaan yang dimiliki oleh desa tersebut. Keberhasilan BUMDes tidak hanya dilihat dari berapa lamanya BUMDes itu berjalan akan tetapi dilihat juga dari kontribusi BUMDes pada desa maupun masyarakat desa dalam memajukan perekonomian dan kesejahteraan masyarakat (Kohen, 2018). Keberadaan BUMDes sangat berpengaruh pada bidang ekonomi dan sosial yang membawa perubahan interaksi antar warga dan juga memberikan peningkatan Pendapatan Asli Desa (PAD) (Anggaraeni, 2016). Pengelolaan BUMDes Ijen Lestari pada bidang ekonomi dan sosial berdampak positif pada perekonomian desa baik secara langsung maupun tidak langsung dan keterlibatan masyarakat dalam menjual makanan lokal dan homestay juga memberi dampak positif terhadap perekonomian desa (Setyobekti, 2018).

Pembentukan BUMDes di Desa Selesen pada unit simpan pinjam dan usaha pasar desa menunjukkan hasil yang positif dan telah memberikan kontribusi dalam meningkatkan pengelolaan potensi desa, perekonomian desa, dan Pendapatan Asli Desa (PAD) (Alkadafi, 2014). 
Implementasi BUMDes di Desa Babadan berhasil menghadapi masalah masyarakat dengan menyediakan modal bagi Rumah Tangga Miskin (RTM) dan masyarakat merasa puas dengan kinerja BUMDes desa Babadan (Nugroho, 2015). Berbeda dengan penelitian Kurniasih (2014) bahwa kinerja BUMDes di Banyumas belum cukup berhasil, karena kurang optimal dalam memanfaatkan sumber daya. Keberadaan BUMDes di Banyumas belum bisa dirasakan oleh masyarakat sekitar dan pengelolaan BUMDes belum bisa professional dan bertanggungjawab. Penelitian Agunggunanto, Ariati, Kushartono \& Darwanto (2016) menunjukkan bahwa pembentukan BUMDes di Kabupaten Jepara sudah bisa membantu meningkatkan perekonomian desa. Namun masih banyak juga kendala dalam pengelolaan BUMDes seperti usaha yang terbatas, sumber daya manusia yang terbatas dan kurangnya partisipasi masyarakat terhadap BUMDes.

Pemendes No 4 Tahun 2015 mengatur tentang tanggungjawab pelaksanaan BUMDes yang menyatakan pelaksana operasional melaporkan pertanggungjawaban pelaksanaan BUMDes kepada Penasehat yang secara ex-office oleh Kepala Desa. Pada dasarnya BUMDes didirikan sebagai pilar ekonomi desa yang berfokus pada lembaga sosial (social institution) dan komersial (commercial institution). Pasal - pasal yang sudah dirumuskan dapat diambil kesimpulan bahwa tujuan dari pendirian BUMDes adalah meningkatkan ekonomi desa dari berbagai macam potensi yang dimiliki desa. Keberhasilan BUMDes untuk meningkatkan desa maka harus berprinsip kooperatif, partisipatif, emansipatif, transparansi, akuntabel dan sustainable.

BUMDes mempunyai peran dalam meningkatkan pendapatan desa dan harus terlihat hasilnya, maka perlu dilaporkan secara transparan informarsi-informasi kepada pihak-pihak yang membutuhkan (Nuha \& Masrunik, 2017). Laporan keuangan menjadi informasi yang sangat diperlukan untuk mencerminkan suatu kondisi instansi tersebut dan membantu instansi dalam pengambilan keputusan untuk keberlanjutan jangka panjang suatu instansi (Irawati \& Martanti, 2018). Kurangnya komunikasi dan sosialisasi yang memunculkan ketidakpercayaan masyarakat kepada pengelolaan BUMDes yang menuntut adanya transparansi dan akuntabilitas pengelolaan BUMDes, meskipun keberadaan BUMDes sudah memberikan peningkatan Pendapatan Asli Daerah (Anggraeni, 2016). Transparansi adalah suatu keterbukaan informasi yang harus dipahami masyarakat, penting bagi pelaksana fungsi pemerintah dan menjadi instrumen untuk menyelamatkan uang rakyat dari penyelewengan atau korupsi (Nuha \& Masrunik, 2017).

Pelaporan keberlanjutan berperan dalam bisnis interval BUMDes dan UKM untuk membawa ketingkat berikutnya dan model pelaporan keberlanjutan membuat bisnis interval lebih transparan dalam penyampaian informasi keuangan maupun non keuangan (Kurniawan, 2018). Dalam menjalankan fungsi pemerintah penting adanya transparansi atau keterbukaan dalam berbagai hal supaya segala sesuatunya dapat dipertanggungjawabkan seperti dalam QS. Al Baqarah (2) Ayat 283 berbunyi:

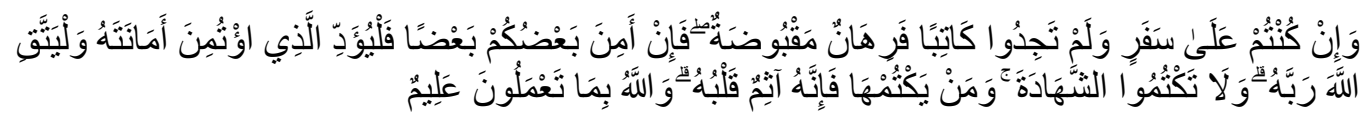

Artinya :

“Dan jika kamu dalam perjalanan sedang kamu tidak mendapat seorang penulis, maka hendaklah ada barang jaminan yang dipegang. Tetapi, jika sebagian kamu mempercayai sebagian lain, hendaklah dipercayai itu menunaikan amnatnya (utangnya) dan hendaklah dia bertakwa kepada Allah, Tuhannya. Dan janganlah kamu menyembunikan kesaksian, karena barangsiapa menyembunyikannya, sungguh, hatinya kotor (berdosa). Allah Maha Mengetahui apa yang kamu kerjakan.”

Pada penelitian ini, penulis membatasi penulisan yaitu tentang pengelolaan Badan Usaha Milik Desa hanya membahas tahapan perencanaan pengelolaan yang telah dilaksanakan. Maka penelitian ini berfokus bagaimana prinsip Akuntabilitas dan Transparansi dilakukan oleh BUMDes, dalam tahapan perencanaan yang dapat dipertanggungjawabkan dan dapat diketahui oleh masyarakat desa. Peneliti melihat bahwa keberhasilan terbentuknya BUMDes di Kabupaten Klaten ini sangat pesat. Akuntabilitas dan transparansi merupakan indikator 
terpenting dalam suatu pengelolaan aset baik milik Daerah maupun milik Desa, kerena jika suatu lembaga tidak akuntabel dan tidak transparan maka kemungkinan akan terjadi penyelewengan dalam pelaksanaannya oleh sebab itu akuntabilitas dan transparansi menjadi penting dalam suatu pengelolaan asset.

Keberadaan akuntabilitas sangat penting terhadap terciptanya penyelenggaraan pemerintah yang baik. Kelembagaan pemerintah yang berakuntabilitas publik berarti Lembaga tersebut senantiasa dapat mempertanggungjawabkan segala kegiatan yang diamanatkan kepada Lembaga tersebut (Nahruddin, 2017). Akuntabilitas dalam pengelolaan pemerintah daerah diartikan sebagai kewajiban pemda untuk mempertanggungjawabkan pengelolaan dan pelaksanaan pemerintahan di daerah dalam menuju otonomi daerah untuk mencapai tujuan yang telah ditetapkan melalui media pertanggungjawaban yang terukur baik dalam segi kualitas dan kuantitas (Nafidah \& Suryaningtyas, 2016). Transparancy mengisyaratkan bahwa laporan tahunan tidak hanya dibuat tetapi juga dapat diakses oleh masyarakat, karena aktivitas pemerintah adalah dalam rangka menjalankan amanat rakyat. Transparancy merupakan suatu kebebasan untuk mengakses aktivitas politik, ekonomi pemerintah dan keputusankeputusannya (Nahruddin, 2017).

Setelah ditetapkannya Undang-Undang No 32 Tahun 2004 Tentang Pemerintah Daerah, Pemerintah Kabupaten Klaten mulai mendirikan BUMDes .

Tabel 1

Daftar Jumlah BUMDes di Kabupaten Klaten

\begin{tabular}{clcc}
\hline No & \multicolumn{1}{c}{ Kecamatan } & Jumlah Desa & Jumlah BUMDes Berdiri \\
\hline 1. & Bayat & 18 & 14 BUMDes \\
2. & Cawas & 20 & 13 BUMDes \\
3. & Ceper & 18 & 17 BUMDes \\
4. & Delanggu & 16 & 12 BUMDes \\
5. & Gantiwarno & 16 & 9 BUMDes \\
6. & Jatinom & 18 & 12 BUMDes \\
7. & Jogonalan & 18 & 16 BUMDes \\
8. & Juwiring & 19 & 11 BUMDes \\
9. & Kalikotes & 7 & 4 BUMDes \\
10. & Karanganom & 19 & 19 BUMDes \\
11. & Karangdowo & 19 & 10 BUMDes \\
12. & Karangnongko & 14 & 14 BUMDes \\
13. & Kebonarum & 7 & 7 BUMDes \\
14. & Kemalang & 13 & 13 BUMDes \\
15. & Klaten Selatan & 12 & 10 BUMDes \\
16. & Klaten Tengah & 9 & 1 BUMDes \\
17. & Klaten Utara & 8 & 5 BUMDes \\
18. & Manisrenggo & 16 & 15 BUMDes \\
19. & Ngawen & 13 & 12 BUMDes \\
20. & Pedan & 14 & 7 BUMDes \\
21. & Polanharjo & 18 & 14 BUMDes \\
22. & Prambanan & 16 & 10 BUMDes \\
23. & Trucuk & 18 & 15 BUMDes \\
24. & Tulung & 18 & 12 BUMDes \\
25. & Wedi & 19 & 17 BUMDes \\
26. & Wonosari & 18 & BUMDes \\
& & 401 & Total
\end{tabular}

Sumber: Data Badan Usaha Milik Desa (BUMDes) Tahun 2019

Tahun 2019 Pemerintah Kabupaten Klaten sudah mencapai 298 unit BUMDes yang terbentuk dari 401 desa dengan beragam potensi yang dimilikinya. Pertumbuhan terlihat sangat 
pesat pada tahun 2015 - 2018 yaitu sebanyak 268 BUMDes yang terbentuk. Harapannya agar desa-desa lain termotivasi untuk membentuk BUMDes yang menjadi salah satu alternatif untuk meningkatkan kesejahteraan masyarakat.

Tabel 2

Pertumbuhan BUMDes di Kabupaten Klaten pada tahun 2009-2019

\begin{tabular}{lcc}
\hline No & Tahun & BUMDes Berdiri \\
\hline 1. & $2009-2010$ & 6 BUMDes \\
2. & $2011-2012$ & 7 BUMDes \\
3. & $2013-2014$ & 14 BUMDes \\
4. & $2015-2016$ & 114 BUMDes \\
5. & $2017-2018$ & 154 BUMDes \\
6. & 2019 & 3 BUMDes \\
& Total & 298 BUMDes \\
\hline
\end{tabular}

Sumber : Data Badan Usaha Milik Desa (BUMDes) Tahun 2019

Pengelolaan BUMDes yang menganut prinsip tata kelola yang baik serta didukung oleh aspek kepemimpinan kepala desa, aspek sosial budaya, dan aspek lingkungan fisik daerah setempat menjadi faktor kesuksesan BUMDes sehingga mampu memberi manfaat kepada masyarakat dan desa yang pada akhirnya keberadaan BUMDes diharapkan akan dapat meningkatkan kesejahteraan masyarakat desa (LPPI, 2018). Peneliti memilih melakukan penelitian di Kabupaten Klaten karena pertumbuhan BUMDes di Kabupaten Klaten yang sangat pesat dan apakah dengan pertumbuhan BUMDes yang sangat pesat tersebut sudah diimbangi dengan pengelolaan BUMDes yang baik guna meningkatkan kesejahteraan masyarakat. Dari tinjauan tersebut maka perlu untuk dikaji lebih lanjut mengenai akuntabilitas dan transparansi dalam pengelolaan BUMDes di Kabupaten Klaten.

Accountability merupakan wujud dari tata kelola yang baik (good governance) dalam suatu organisasi pelayanan masyarakat untuk menjaga kepercayaan masyarakat dan menjaga eksitensi badan usaha (Fitriana, Utami \& Hapsari, 2018) . Transparancy sangat penting untuk meningkatkan publikasi kepada masyarakat agar masyarakat mengetahui dengan jelas kondisi aset yang dimiliki (Irawati \& Martanti, 2018). Fokus penelitian ini menggambarkan bagaimana keberlanjutan pengelolaan BUMDes dimasa yang akan datang, tanggungjawab dari pengelolaan BUMDes dan transparansi pengelolaan BUMDes yang diberikan kepada masyarakat di Pemerintah Kabupaten Klaten. Dalam penelitian ini diharapkan dapat memberikan jawaban mengenai tanggungjawab dan transparansi pengelolaan BUMDes di Pemerintah Klaten ini sebagai peningkatan kesejahteraan masyarakat. Berdasarkan masalah yang ada, maka peneliti memberikan batasan pada penelitian yang dilakukan. Batsan ini bertujuan agar pembahasan yang dilakukan dalam penelitian hanyalah masalah yang akan diteliti oleh peneliti. Ruang lingkup dalam penelitian ini terbatas pada lokasi penelitian dan informan yang dipilih. Permasalahan yang dibahas dalam penelitian ini terbatas yaitu Apakah keberadaan BUMDes di Kabupaten Klaten mapu meningkatkan kesejahteraan masyarakat pedesaan?.

\section{TINJAUAN LITERATUR DAN PERUMUSAN HIPOTESIS}

\section{Teori Social Enterprise}

Di Korea Selatan social enterprise sudah diperkenalkan oleh pemerintah pada saat krisis keuangan Tahun 1997 dan krisi ekonomi Tahun 2008 untuk mengatasi pengangguran dan kemiskinan bagi yang kurang eberuntung secara sosial (Adrews et al., 2013). Social enterprise di Amerika Serikat sudah harus berbadan hukum dan diakui oleh undang-undang bagi pengembangan sosial sebagai pelaku kesejahteraan (Pestoff \& Hulga, 2015). Social enterprise dibentuk untuk menangani permasalahan sosial dan menciptakan kekayaan ekonomi melalui pasokan produk atau layanan yang bisa menghasilkan kuallitas hidup masyarakat (Vazquez-Maguirre \& Portales, 2018). 
Sehingga social enterprise bukan hanya sebagai proyek atau kegiatan lokakarya yang berfokus untuk memperkerjakan orang yang terpinggirkan, tetapi sebagai kegiatan kewirausahaan berkelanjutan yang memiliki peran sendiri dalam inovasi bisnis di masyarakat (Rinkinen et al., 2016).

\section{Dasar Hukum BUMDes}

UU No 32 Tahun 2004 Pasal 2013 yaitu desa dapat mendirikan BUMDes harus sesuai dengan potensi desa masing-masing, BUMDes harus berpedoman terhadap peraturan perundangundangan, BUMDes bisa melakukan pinjaman sesuai dengan peraturan perundang-undangan yang telah ditetapkan. Pemendesa No 4 Tahun 2015 menjadi penjelas landasan hukum mengenai keberadaan BUMDes dan tata kelola BUMDes. Pemedesa No 4 Tahun 2015 ini berisi tentang bagaimana proses berdirinya BUMDes, jenis usaha yang boleh dilakukan, modal BUMDes, siapa yang berhak dalam mengelola BUMDes, pelaporan dan pertanggungjawaban dari BUMDes.

UU No 6 Tahun 2014 yang berisi bahwa desa dikaitkan dengan Badan Usaha Milik Desa (BUMDes) yaitu badan usaha yang digunakan untuk mengelola asset, pelayanan dan usaha lainnya sebagai kesejahteraan masyarkat yang modalnya berasal dari kekayaan desa itu sendiri. Pasal 87 ayat (1) yaitu tentang pendiirian (BUMDes) pada desa, ayat (2) BUMDes dikelola degan kegotongroyongan dan kekeluargaan, ayat (3) usaha BUMDes bisa dibidang ekonomi maupun pelayanan umum sesuai dengan peraturan yang ditetapkan. Pasal 88 yaitu mengenai tentang pendirian BUMDes, pasal 89 yaitu manfaat dari hasil BUMDes itu sendiri seperti untuk pemberdayaan masyarakat desa, pembangunan desa, pengembangan usaha dll. Pasal 90 berisi tentang arah pengembangan BUMDes bagi masyarakat desa.

\section{Accountability}

Indikator penentu keberhasilan akuntabilitas adalah meningkatnya kepercayaan dan kepuasan publik terhadap pengelolaan keuangan oleh pemerintah desa, timbulnya kesadaran masyarakat akan hak untuk menilai penyelenggaraan pemerintah desa, berkurangnya kasus korupsi, kolusi dan nepotisme dalam lingkup pemerintah desa (Ningrum \& Hermawan, 2017). Akuntabilitas pengelolaan BUMDes adalah menilai tingkat perencanaan BUMDes dengan melihat proses perencanaan yang partisipatif, perencanaan yang akomodatif, perencanaan yang adil serta perencanaan yang representatif. Tingkat akuntabilitas pelaksanaan program kegiatan BUMDes dapat dilihat dengan tingkat efektivitas dan transparansi dari proses penganggaran, perencanaan, penyusunan dan pelaksanaan harus benar-benar dilaporkan dan dapat dipertanggungjawabkan kepada pihak yang berkepentingan (Pramita, 2018) .

\section{Transparancy}

Permendagri No. 113 Tahun 2014 menyatakan bahwa keuangan desa harus dikelola berdasarkan asas transparan, karena asas transparan atau aspek keterbukaan akan menjamin kebebasan bagi setiap orang untuk mendapatkan informasi atas penyelenggaraan pemerintah, yaitu informasi atas kebijakan pemerintah desa dan pengelolaan keuangan desa. Transparansi menjadi fungsi penting terkait informasi aktual maupun faktual dan dapat digunakan masyarakat sebagai bentuk pengawasan terhadap pemerintah terhadap tindakan korupsi atau manipulasi pertanggungjawaban anggaran dan membandingkan kinerja keuangan yang telah dicapai dengan kinerja keuangan yang dianggarkan (Ningrum \& Hermawan, 2017). Menurut Irawati \& Martanti (2018) prinsip transparansi dapat diukur melalui indikator sebagai berikut :

a. Mekanisme menjamin sistem keterbukaan dan standarisasi dari semua proses pelayanan publik.

b. Mekanisme yang memfasilitasi pertanyaan-pertanyaan publik tentang berbagai kebijakan dan pelayanan publik maupun proses didalam sektor publik.

c. Mekanisme pelaporan maupun penyebaran informasi penyimpanan tindakan aparat publik di dalam kegiatan melayani. 


\section{Kesejahteraan Masyarakat}

Indonesia merupakan salah satu negara berkembang yang terus berupaya melakukan pembangunan untuk meningkatkan kesejahteraan masyarakatnya. Kesejahteraan masyarakat menunjukkan ukuran hasil pembangunan masyarakat dalam mencapai kehidupan yang lebih baik yang meliputi (Hukom, 2014) :

a. Peningkatan kemampuan dan pemerataan distribusi kebutuhan dasar seperti makanan, perumahan, kesehatan, dan perlindungan.

b. Peningkatan tingkat kehidupan, tingkat pendapatan, pendidikan yang lebih baik, dan peningkatan atensi terhadap budaya dan nilai- nilai kemanusiaan.

c. Memperluas skala ekonomi dan ketersediaan pilihan sosial dari individu.

Konsep negara kesejahteraan sangat erat kaitannya dengan kebijakan sosial (social policy) yang di banyak negara mencakup strategi dan upaya-upaya pemerintah dalam meningkatkan kesejahteraan warganya, terutama melalui perlindungan sosial (social protection) yang mencakup jaminan sosial baik berbentuk bantuan sosial dan asuransi sosial, maupun jaring pengaman sosial (social safety nets). Ada lima bidang utama untuk menjelaskan konsep kesejahteraan, yaitu: bidang kesehatan, bidang pendidikan, bidang perumahan, bidang jaminan sosial, dan bidang pekerjaan sosial dengan kebutuhan-kebutuhan yang diinginkannya. Untuk itu perlu di identifikasi tiga elemen pokok, yaitu (Agus Suryono, 2014):

a. Sejauhmana masalah-masalah sosial ini diatur.

b. Sejauhmana kebutuhan-kebutuhan dipenuhi.

c. Sejauhmana kesempatan dan peluang untuk meningkatkan taraf hidup rakyat dapat disediakan atau di fasilitasi.

Berdasarkan Undang - undang No 11 Tahun 2009 tentang Kesejahteraan Sosial menyebutkan bahwa Kesejahteraan Sosial adalah kondisi terpenuhinya kebutuhan material, spriritual dan sosial. Tujuan dari kesejahteraan berdasarkan UU Nomor 11 Pasal 3 Tahun 2009 adalah sebagai berikut:

a. Meningkatkan taraf kesejahteraan, kualitas, dan kelangsungan hidup.

b. Memulihkan fungsi sosial dalam rangka mencapai kemandirian.

c. Meningkatkan ketahanan sosial masyarakat dalam mencegah dan menangani masalah kesejahteraan sosial.

d. Meningkatkan kemampuan dan kepedulian masyarakat dalam penyelenggaraan kesejahteraan sosial secara melembaga dan berkelanjutan.

e. Meningkatkan kualitas manajemen penyelenggaraan kesejahteraan sosial.

Upaya memberdayakan masyarakat tersebut harus dilakukan melalui tiga cara, yaitu (Tama \& Yunuardi, 2013):

a. Menciptakan suasana atau iklim yang memungkinkan potensi masyarakat berkembang.

Pemberdayaan masyarakat dilakukan dengan cara pemberian motivasi, pendidikan dan pelatihan serta membangkitkan kesadaran akan potensi yang dimiliki agar dapat berkembang dan berkontribusi terhadap pembangunan desa sehingga berdampak pada kesejahteraan hidupnya.

b. Memperkuat potensi atau daya yang dimiliki masyarakat (empowering)

Memberikan pelatihan secara rutin untuk meningkatkan potensi masyarakat dalam memanfaatkan BUMDES dan mengembangkannya sehingga dapat tercipta banyak peluang 
c. Memberdayakan juga berarti melindungi

Di dalam masyarakat banyak terdapat perbedaan skill. Oleh karena itu perlu adanya intervensi dari pemerintah desa untuk melindungi masyarakat yang lemah agar tidak bertambah lemah yaitu dengan cara memberi pengertian mengenai BUMDES agar masyarakat yang belum mengerti menjadi mengerti dan dapat berpartisipasi dalam pemanfaatan BUMDES.

Kesejahteraan adalah suatu kondisi masyarakat dimana kebutuhan dasarnya terpenuhi seperti kecukupan dan mutu pangan, sandang, papan, kesehatan, Pendidikan, lapangan pekerjaan, dan kebutuhan dasar lainnya seperti lingkungan uang bersih, aman dan nyaman. Peningkatan kesejahteraan ekonomi masyarakat akan dinilai dnegan menggunkan indikator peningkatan pendapatan masyarakat dan pemenuhan kebutuhan kehidupan. Berikut adalah indikator tentang kesejahteraan masyarakat :

a. Peningkatan Pendapatan Masyarakat.

b. Peningkayan Taraf Hidup Masyarakat.

c. Terpenuhinya Kebutuhan Dasar

\section{METODE PENELITIAN}

Lokasi yang dipilih dalam penilitian ini yaitu di Kabupaten Klaten. Penelitian mengambil lokasi di Kabupaten Klaten karena pertumbuhan terbentuknya BUMDes yang sangat signifikan dan sudah terbentuk 298 BUMDes dari 401 desa yang. Pertumbuhan signifikan terlihat pada tahun 2015 - 2018 yaitu sebanyak 268 BUMDes yang terbentuk. Adapun jenis penelitian ini adalah penelitian deskriptif dan kualitatif. Penelitian deskriptif dalam hal ini adalah untuk mendiskripsikan fenomena yang terjadi BUMDes di Kabupaten Klaten.

Jenis data penelitian yang digunakan yaitu data primer. Data primer dikumpulkan dengan menggunakan instrumen pengumpulan data berbentuk observasi yaitu mengumpulkan data dengan terjun langsung ke lapangan agar mengetahui lebih tentang dampak dan pengelolaan BUMDes yang dilakukan di Kabupaten Klaten itu sendiri dan wawancara peneliti terhadap narasumber. Narasumber meliputi Ketua BUMDes, Staff BUMDes, Kepala Desa, dan Tokoh Masyarakat sekitar. Wawancara dilakukan dengan memberi pertanyaan kepada infroman yang bersangkutan secara mendalam. Wawancara yang dilakukan addalah wawancara tidak berstruktur kepada seluruh informan yang dipilih dengan pedoman yang sudah ditentukan.

Teknik pemilihan informan sangat penting dikarenakan informanlah yang nantinya akan menjadi sumber informasi dalam penelitian. Penelitian ini menggunakan metode purposive sampling yaitu memilih 4 BUMDes dari masing-masing BUMDes yang sudah dikategorikan maju, berkembang, tumbuh dan dasar kemudian memilih informan berdasarkan kriteria dan bersangkutan dengan BUMDes. Informan yang dipilih sesuai kriteria dan bersangkutan yaitu Ketua BUMDes, Staff BUMDes, Kepala Desa, dan Tokoh Masyarakat sekitar. Instrument dalam penelitian ini adalah alat bantu yang digunakan oleh peneliti dalam pengumpulan data penelitian secara sistematis dan lebih mudah.

Teknik pengambilan data dilakukan dengan wawancara dengan informan yang telah ditentukan. Wawancara digunakan sebagai upaya untuk mendapat informasi yang dilakukan tidak menyimpang dari tujuan peneliti dan disusun tidak hanya berdasarkan tujuan penelitian, tetapi juga berdasarkan teori yang berkaitan dengan yang akan diteliti. Teknik analisis data yang dilakukan adalah reduksi data (Data Reduction) yaitu sebagai proses pemilihan, pemisahan pada penyederhanaan, pengabstrakan dan transformasi data kasar yang muncul dari catatan-catatan tertulis lapangan. Data yang diperoleh dari lapangan akan dituangkan dalam deskripsi yang lengkap dan terperinci maka perlu dicatat secara teliti dan rinci. Mereduksi data yaitu merangkum, memilih yang pokok-pokok, dan fokus pada hal-hal yang penting dan sesuai dengan rumusan masalah. Reduksi data merupakan suatu bentuk analisis yang menajamkan, menggolongkan, membuang yang tidak perlu dan mengorganisasi data sehingga dapat diambil kesimpulan-kesimpulan yang bisa 
ditarik dan diverifikasi. Penyajian Data (Data Display) yaitu gambaran atau bagian dari penelitian yang bertujuan untuk kemudahan penelitian. Penyajian data (data display) dituangkan dengan mendeskripsikan dari hasil wawancara dan dapat memberikan kemungkinan dalam penarikan kesimpulan. Penarikan kesimpulan (Concluting Drawing) yaitu melakukan verifikasi terus menerus dalam proses penelitian berlangsung selama pengumpulan data. Kesimpulan dituangkan masih bersifat sementara dan masih bisa berubah jika terdapat bukti yang kuat dalam mendukung tahap pengumpulan data selanjutnya dan penarikan kesimpulan dilakukan dari hasil wawancara yaitu intisari dari rangkaian kategori hasil penelitian.

\section{HASIL DAN PEMBAHASAN}

Hasil penelitian diatas merupakan proses penelitian lapangan yang telah dilakukan peneliti selama kurun waktu Oktober sampai November 2019 dengan pemenuhan persyaratan administrasi penelitian dari pengurusan surat izin penelitian mulai dari perizinan Universitas Muhammadiyah Yogyakarta, Badan Perencanaan Pembangunan Daerah (BAPPEDA) Kabupaten Klaten, hingga Badan Usaha Milik Desa (BUMDes) di Kabupaten Klaten yang dijadikan sampel oleh peneliti, dan informan yang dipilih peneliti yaitu Ketua BUMDes, Staff BUMDes, Kepala Desa, Tokoh Masyarakat yang berdomisili di Kabupaten Klaten. Badan Usaha Milik Desa (BUMDes) yang dijadikan sampel peneliti ada 4 BUMDes berdasarkan kategori BUMDes di Kabupaten Klaten yaitu BUMDes maju, berkembang, tumbuh dan dasar dengan mengambil masing-masing kategori satu BUMDes. Penelitian ini menggunakan metode kualitatif dengan pendekatan deskriptif tentang dampak keberadaan Badan Usaha Milik Desa (BUMDes) terhadap peningkatan kesejahteraan masyarakat desa.

Setelah peneliti melakukan wawancara dan observasi, maka berikut ini diuraikan mengenai dampak keberadaan Badan Usaha Milik Desa terhadap peningkatan kesejahteraan masyarakat desa. Salah satu cara untuk mengelola ekonomi masyarakat desa adalah dengan didirikannya Badan Usaha Milik Desa (BUMDes). Pendirian dan pengelolaan Badan Usaha Milik Desa (BUMDes) adalah perwujudan dari pengelolaan ekonomi produktif desa yang dilakukan secara kooperatif, partisipatif, emansipatif, transparansi, akuntabel, dan sustainable. Empat tujuan utama didirikan Badan Usaha Milik Desa (BUMDes) yaitu meningkatkan perekonomian desa, meningkatkan pendapatan asli desa, meningkatkan pengolahan potensi desa sesuai dengan kebutuhan masyarakat, menjadi tulang punggung pertumbuhan dan pemerataan ekonomi desa, maka perlu pengelolaan yang efektif, efisien, professional dan mandiri agar dapat mencapai tujuan Badan Usaha Milik Desa (BUMDes) (Ningrum \& Hemawan, 2017).

Berdasarkan hasil wawancara dan observasi yang dilakukan peneliti ke masing-masing Badan Usaha Milik Desa (BUMDes) yang dijadikan sampel bahwa semua BUMDes sudah memiliki dasar hukum sesuai peraturan desa yang dibentuk dengan tujuan utamanya untuk mensejahterakan masyarakat desa seperti yang sudah dijelaskan pada UU No 11 Pasal 3 Tahun 2009 kesejahteraan itu meliputi peningkatan kualitas hidup, memulihkan fungsi sosial dalam mencapai kemandirian, ketahanan sosial. Sesuai dengan Teori Social Enterprise yaitu social enterprise berdiri dengan badan hukum dan diakui oleh undang-undang bagi pengembangan sebagai pelaku kesejahteraan (Pestoff \& Hulga, 2015). Perekrutan tenaga/staff dikhususkan masyarakat desa setempat dengan tujuan untuk mengurangi tingkat pengangguran sejalan dengan Teori Social Enterprise menurut Adrews et al (2013) bahwa social enterprise diperkenalkan pemerintah untuk mengatasi pengangguran dan kemiskinan bagi yang kurang beruntung secara sosial dan ekonomi. Hasil wawancara menunjukkan bahwa masing-masing BUMDes sudah memiliki unit usaha yang sudah berjalan dengan merekrut tenaga/staff yang dikhususkan oleh masyarakat dimana BUMDes itu didirikan dan sudah bisa memberikan remunerasi bagi tenaga/staff meskipun dari hasil analisis yang peneliti lakukan ada satu BUMDes yang belum memberikan remunerasi dan masih bersifat sosial

karena omset yang didapat belum banyak tetapi antusias tenaga/staff yang tinggi untuk bekerja yang bersifat sosial dan komitmen yang tinggi untuk tetap memajukan BUMDes tersebut. 
Tabel 3

Hasil Penelitian

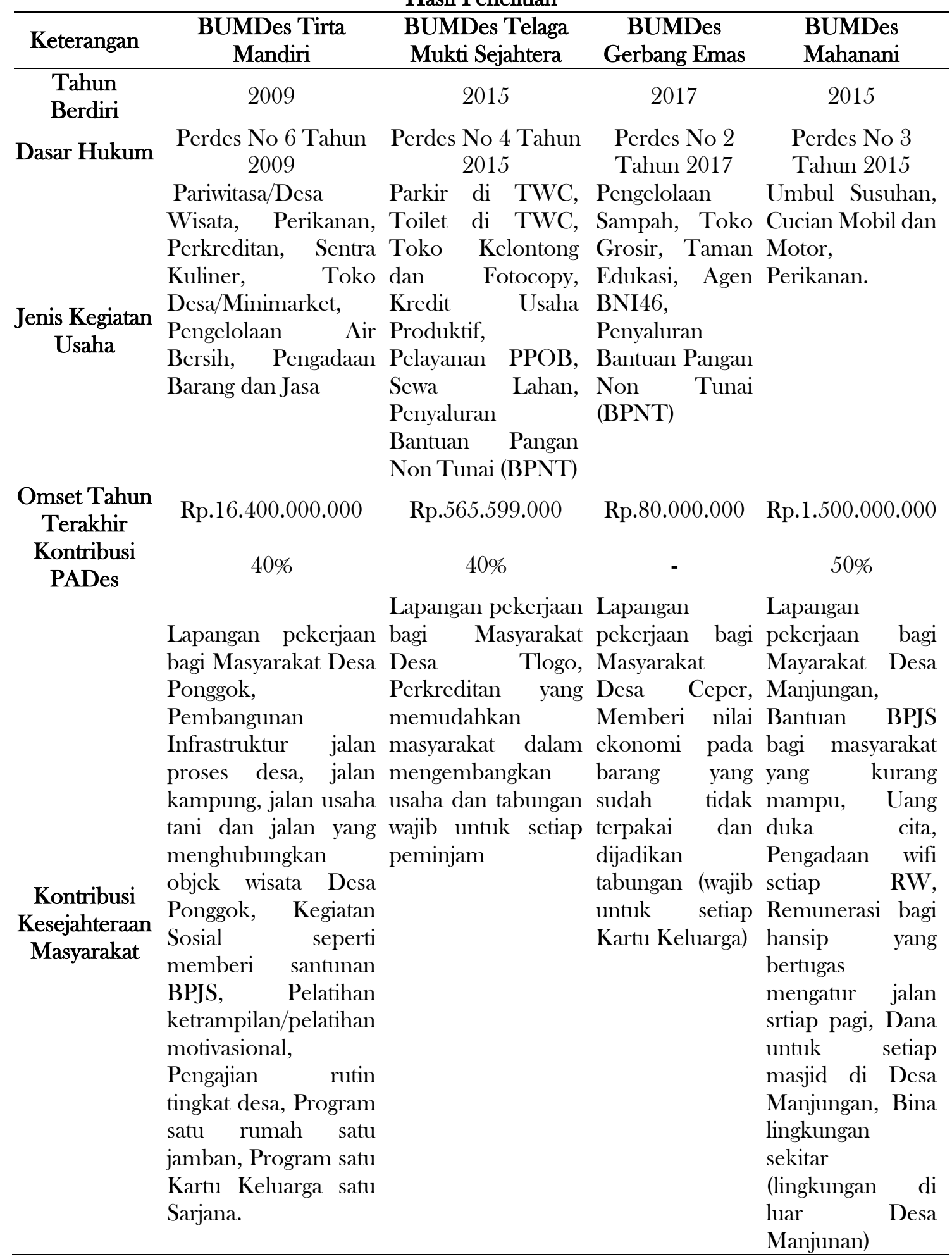

Keberadaan (BUMDes) tidak dipungkiri bisa membawa perubahan dari segi ekonomi maupun sosial. Monitoring dan evaluasi yang selalu dilakukan (BUMDes) memberikan arahan dalam pengelolaan (BUMDes) dan menjadikan pengelolaan yang lebih baik untuk kedepan. Pembagian keuntungan dan pelaporan pertanggung jawaban yang jelas dan dilaporkan secara berkala menjadikan suatu nilai positif kepada masyarakat akan pandangan terhadap BUMDes, 
meskipun laporan tersebut belum bisa diakses oleh publik tetapi selalu dilaporkan di musyawarah desa. Komunikasi dan sosialisasi merupakan hal penting yang harus dilakukan BUMDes. Kurangnya komunikasi dan sosialiasi memunculkan ketidakpercayaan masyarakat terhadap transparansi dan akuntabilitas kepada pengelolaan BUMDes (Anggraeni, 2016). Sistem pencatatan pelaporan yang sudah baik dari masing-masing BUMDes ada yang sudah menggunakan SAK ETAP akan tetapi juga masih banyak yang menggunakan pencatatan yang biasa karena belum bisa menggunakan sistem pencatatan yang sesuai dengan aturan. Pengambilan keputusan di BUMDes tidak menggunakan mekanisme musyawarah desa tetapi pihak internal yang akan memutuskan, meskipun keputusan berada di kebijakan pihak internal tetapi nanti tetap akan disampaikan di musyawarah desa.

Kontribusi BUMDes dalam rangka kemandirian ekonomi desa dan peningkatan PADes sudah bisa dikatakan memenuhi, dimana keuntungan bersih BUMDes dialokasikan untuk pemasukan Desa. Keuntungan BUMDes juga dialokasikan untuk beberapa pihak dengan prosentase yang berbeda. Berdasarkan hasil analisis di atas, bahwa alokasi keuntungan BUMDes sudah diperuntukkan desa meskipun ada salah satu BUMDes yang belum bisa berkontribusi dalam memberikan keuntungan untuk PADes, tetapi BUMDes ini akan tetap berusaha agar bisa memberi keuntungan untuk PADes dengan beberapa strategi yang akan diambil termasuk menambah unit usaha dan mengembangkan unit usaha yang sudah ada, meskipun BUMDes ini belum bisa berkontribusi ke PADes tetapi antusias masyarakat untuk mendukung berkembangnya BUMDes ini sangat kuat dan para masyarakat sangat memiliki jiwa sosial yang tinggi demi kesejahteraan.

Pendapat masyarakat mengatakan bahwa dengan berdirinya BUMDes ini akan bermanfaat bagi peningkatan kesejahteraan masyarakat. Fasilitas-fasilitas yang diberikan oleh BUMDes untuk masyarakat itu juga menjadi nilai positif akan pandangan masyarakat terhadap berdirinya BUMDes, meskipun dari hasil analisis penelitian ini ada salah satu BUMDes yang belum bisa berkontribusi dalam PADes tetapi BUMDes tersebut memiliki strategi dengan membuat unit usaha yang dimana unit usaha itu dibuat dengan tujuan untuk membuat masyarakat menjadi memiliki tabungan dengan pengumpulan barang-barang bekas yang sekiranya sudah tidak terpakai dan itu diwajibkan per Kartu Keluarga jadi per Kartu Keluarga mempunyai tabungan wajib, hal itulah yang menjadikan masyarakat yakin kalau keberadaan BUMDes bisa meningkatkan kesejahteraan masyarakat meskipun belum bisa berkontribusi dalam PADes.

Permasalahan yang sering mengemuka adalah permasalahan akan sumber daya manusia dan masalah waktu. Faktor sumber daya manusia yang mengelola BUMDes menjadi kelemahan dalam megembangkan BUMDes karena ada pengurus BUMDes yang rangkap jabatan dengan lembaga lain, sehingga pengurus lebih fokus ke pekerjaan utamanya daripada fokus ke BUMDes, sehingga waktu untuk mengelola/memantau BUMDes menjadi kurang efisien.

\section{KESIMPULAN}

Berdasarkan hasil penelitian dengan Teknik wawancara yang telah dilakukan oleh peneliti dengan beberapa Ketua BUMDes, Staff BUMDes, Kepala Desa, dan Tokoh Masyarakat sekitar maka dapat diambil kesimpulan. Sesuai data yang diperoleh peneliti, bahwa keberadaan BUMDes membawa perubahan di bidang ekonomi maupun sosial. Bidang ekonomi seperti mengurangi pengangguran di desa itu sendiri, sudah bisa memberikan remunerasi bagi staff/karyawan yang sudah bekerja di BUMDes, memberikan PADes sebanyak 40\% dari hasil bersih BUMDes, memberikan pinjaman untuk masyarakat dalam mengembangkan usaha, adanya tabungan wajib setiap Kartu Keluarga dengan mengumpulkan barang tidak terpakai yang masih memiliki nilai ekonomi kemudian dibeli oleh BUMDes. Bidang sosial yaitu adanya bantuan BPJS bagi masyarakat kurang mampu, uang santunan duka cita, pengadaan wifi setiap RW, dana untuk setiap masjid, bina lingkungan sekitar, program satu rumah satu jamban, pembangunan infrastruktur jalan, pelatihan keterampilan, program satu Kartu Keluarga satu Sarjana dengan memberikan uang perbulan Rp 300.000. Kontribusi BUMDes ini menjadikan masyarakat berpendapat bahwa keberadaan BUMDes bisa meningkatkan kesejahteraan masyarakat. Komunikasi dan sosialisasi antara 
pengelola BUMDes dan masyarakat sangat penting, karena pengelolaan transparan dan akuntabel yang selalu dilakukan BUMDes memberikan kepercayaan kepada masyarakat bahwa BUMDes bisa membawa perubahan dan meningkatkan kesejahteraan masyarkat desa.

Perlunya ada pendampingan untuk peyusunan laporan keuangan yang sesuai dengan standar penyusunan yang berlaku. Profesionalisme menjadi tuntutan bagi pengelola BUMDes karena adanya tenaga/staff yang bekerja paruh waktu yang memiliki pekerjaan lain selain di BUMDes. Perlunya pelatihan keterampilan/diklat tentang manajemen BUMDes kepada tenaga/staff untuk meningkatkan kinerja kelembagaan BUMDes karena terkadang permasalahan muncul dari SDM yang ada.

\section{DAFTAR PUSTAKA}

Ab Samad, N. H., Arshad, R., Asat, S. H., \& Kasim, N. (2017). Sustainability and Accountability of Social Enterprise. Management \& Accounting Review, 16, 181-202.

Addae, A. E. (2018). Pathways to sector selection : A conceptual framework for social enterprises. Nonprofit Management and Leadership, 28(3), 349-365.

Agunggunanto, E. Y. (2016). Pengembangan Desa Mandiri Melalui Pengelolaan Badan Usaha Milik Desa (BUMDes). Jurnal Dinamika Ekonomi dan Bisnis, 67-81.

Agus Taufik Hidayah, A. T., Pujiati, L., Hidyati, N., Hendrawan, S. A., Suprapto, S., \& Ali, N. (2018). Pendampingan Penyusunan Laporan Keuangan Pada Badan Usaha Milik Desa (Bumdes) Lestari Desa Bandung Kecamatan Diwek Jombang. Journal of community service, 2, 15-20.

Andrews, M. (2013). Using Social Enterprises For Social Policy In South Korea: Do Funding And Management Affect Social And Economic Performance?. Public administration and development, 15-27.

Anggraeni, M. R. (2016). Peranan Badan Usaha Milik Desa (BUMDes) Pada Kesejahteraan Masyarakat Pedesaan. Modus Journal, 28(2),155-167.

Baitul, S. (2016). Perkembangan perbankan syariah dari tahun ketahun memang memiliki trend yang amat positif, indikator yang paling terlihat adalah semakin banyaknya Lembaga Keuangan Syariah ( LKS ) yang berdiri dan tersebar di seluruh wilayah Indonesia. 1-10.

Desa, P. K. (2017). Analisis Aspek Transparansi Dan Akuntabilitas Pengelolaan APBDES dan Kemungkinan Berdirinya BUMDES.

Fitriana, R. L. (2018). Pengelolaan Dana : Sisi Akuntabilitas Badan Usaha Milik Desa. Konferensi Regionsl Akuntansi, 1-29.

Hukom, A. (2014). Hubungan Ketenagakerjaan Dan Perubahan Struktur Ekonomi terhadap Kesejahteraan Masyarakat. Journal Ekonomi Kuantitatif Terapan, 120-129.

Ihsan, A. N. (2018). Analisis Pengelolaan Badan Usaha Milik Desa (BUMDes ) Gerbang Lentera Sebagai Penggerak Desa Wisata Lerep. Journal of Politic and Government Studies. 7(11).

Irawati, D., \& Martanti, D. E. (2017). Transparansi Pengelolaan Laporan Keuangan BUMDes Terhadap Pelaporan Aset Desa. Prosiding Seminar Nasional dan Call For Papper Ekonomi dan Bisnis, 41-51.

Junaidi, M. (2015). Milik Desa Berbasis Ekonomi Syariah Di Desa. 111-122.

Kuriawan, P. S. (2018). An Implementation Model of Sustainability Reporting in Village-Owned Enterprise and Small and Medium Enterprise. Journal of Sustainability Accounting and Management, 90-106.

Kurniasih, D. (2014). Problem Pengelolaan Badan Usaha Milik Desa (Bumdes) Di Kabupaten Banyumas. Jurnal Administrasi Publik Dan Politik, 182-188.

Kuznecova, J. (2016). Social Enterprises Startups : Possibilities and Barriers. Journal of Business Management, 70-79.

Lecy, D. R. (2014). Defining the Universe of Social Enterprise: Competing Metaphors. VOLUNTAS: International Journal of Voluntary and Nonprofit Organizations. 
Lestari, V. Q. (2016). Peran Pemerintah Des Dalam Mengelola Badan Usaha Milik Desa (BUMDes). Jurnal Ilmu Social dan Ilmu Politik.

Muammar Alkadafi, S. M. (2015). Penguatan Ekonomi Masyarakat Melalui Pengelolaan Kelembagaan Badan Usaha Milik Desa Menuju Asean Economic Community 2015. Jurnal El-Riyasah, 5(1).

Ningrum, E. S. S., \& Hermawan, S. (2018). Analisis Aspek Transparansi dan Akuntabilitas Pengelolaab APBDES dan Kemungkinan Berdirinya BUMDes. Seminar Nasional dan The 5th Call For Syariah Paper (SANCALL) 2018.

Nugrahaningsih, P., \& Muttaqin, H. (2018). Optimalisasi Peran Bumdes Desa Bulusulur Kecamatan Wonogiri Kabupaten Wonogiri Dalam Membangun Desa Wisata. Prosiding PKM-CSR, 1.

Nugroho, D. A. (2015). Evaluasi Penerapan dan Dampak Program Badan Usaha Milik Desa (BUMDES) Terhadap Kesejahteraan Masyarakat Rumah Tangga Miskin (RTM) di Desa Babadan Kecamatan Karangrejo Kabupaten Tulungagung (Periode Mei 2014-April 201. JESP(7).

Pestoff, V., \& Hulgård, L. (2015). Participatory Governance in Social Enterprise. International Journal of Voluntary and Nonprofit Organizations 27(4).

Pramita, Y. D. (2018). Analisis Pemahaman Permendesa No. 4 Tahun 2015 Dan Pemanfaatan Sistem Informasi Pada Akuntabilitas Pengelolaan Bumdes. Jurnal Analisis Bisnis Ekonomi $16,1-8$.

Ridley-Duff, R., \& Bull, M. (2015). Understanding social enterprise: theory and practice. 2nd edition. London, Sage Publications.

Ridlwan, Z. (2017). Urgensi Badan Usaha Milik Desa (Bumdes) Dalam Pembangun Perekonomian Desa. Fiat Justisia, 424-440.

Rinkinen, S. O. (2016). Social enterprises in regional innovation systems: a review of Finnish regional strategies. European Planning Studies Vol 24, 723-741.

Rural, S. L.-S. (2014). Theory of Governance and Social Enterprise. The USV Annals of Economics and Public Administration. 14, 204-222.

Sari, D. A. (2016). Analisis Faktor-Faktor Yang Mempengaruhi Kesejahteraan Masyarakat Di Kota Bandar Lampung. 5-24.

Setyobakti, M. (2017). Identification Of Business Enterprises BUMDes Based On Social and Economic Aspect. Jurnal Ilmiah Bidang Akuntansi dan Manajemen.

Sufi, W., \& Saputra, T. (2017). Implementation of village empower program in supporting form of institutions of village business institutions (BUMDes). Jurnal Perspektif Pembiayaan dan Pengembangan Daerah.

Sukma U. N., \& Masrunik, E. (2017). Transparansi Sisa Hasil Usaha BUMDes Dalam Perspektif Akuntansi Syari'ah Sebagai Strategi Desa Guna Meningkatkan Pendapatan Desa. Prosiding Seminar Nasional dan Call Paper Ekonomi dan Bisnis, Hal 52-57.

Suryono, A. (2014). Kebijakan Publik Untuk Kesejahteraan Rakyat. Jurnal Ilmiah Ilmu Administrasi, 98 - 102.

Tama, D. O. (2013). Dampak Badan Usaha Milik Desa (Bumdes) Bagi Kesejahteraan Masyarakat Di Desa Karangrajek Kecamatan Wonosari Kabupaten Gunungkidul. Journal of Chemical Information and Modeling. 53, 1689-1699.

Vázquez-Maguirre, M. P., \& Portales, L. (2018). Profits and purpose: Organizational tensions in indigenous social enterprises. Intangible Capital, 14, 604-618. 